[JSRNC 7.3 (2013) 289-314]

JSRNC (print) ISSN 1749-4907

doi: $10.1558 /$ jsrnc.v7i3.289

JSRNC (online) ISSN 1749-4915

\title{
Disaster Movies and the 'Peak Oil' Movement: Does Popular Culture Encourage Eco-Apocalyptic Beliefs in the United States?
}

\author{
Matthew Schneider-Mayerson \\ Rice University, 6100 Main St, \\ Houston, TX 77005, USA \\ Schne641@umn.edu
}

\begin{abstract}
Using two large-scale surveys, I argue that the prevalence of apocalyptic popular culture influences apocalyptic beliefs in the United States. I focus especially on Hollywood disaster movies of the 1990s and 2000s, most of which deal with environmental themes, and participants in the 'peak oil' movement, a quasi-religious American apocalyptic social movement organized around a vision of energy depletion and social collapse. In these surveys, 'peakists' reflect on their relationship with fictional narratives of disaster and destruction. I contend that disaster films influenced major aspects of the 'peak oil' ideology, such as the hope for regeneration (or even a better world) as a result of environmental crisis and social collapse; the tendency towards fatalism; and the imagination of social and environmental change as immediate and explosive instead of gradual. This cultural influence is situated in the context of contemporary responses to other environmental issues, such as climate change.
\end{abstract}

\section{Keywords}

Peak oil, resource depletion, climate change, popular culture, disaster movies, media influence, apocalypticism

Most scholars have assumed that there is some degree of influence between the prevalence of apocalyptic themes in American popular culture and the preponderance of apocalyptic beliefs in the United States, but concrete evidence has rarely been presented. I examine the influence 
of Hollywood disaster movies of the 1990s and 2000s, most of which deal with environmental themes, on the real-world beliefs and actions of participants in the 'peak oil' movement, an apocalyptic social movement organized around a collective vision of oil depletion and social collapse. I present evidence from two large-scale surveys of over 1500 peak oil believers-Americans who believe that oil depletion will lead to an imminent global collapse-including reflections on their relationship with apocalyptic narratives in popular culture. This research suggests that the saturation of apocalyptic themes in American popular culture encourages and shapes the direction of apocalyptic ideologies. After describing the peak oil ideology and assessing the influence of disaster films on this subculture, I demonstrate the ways that peakist bricoleurs have woven threads from Hollywood narratives into their worldview. Finally, I explore the implications of this cultural influence for the study of responses to other environmental issues, such as climate change.

\section{The 'Peak Oil' Movement}

Between 2004 and 2011, over one hundred thousand Americans came to believe that oil scarcity would lead to the imminent collapse of industrial society and the demise of the United States of America. ${ }^{1}$ Billions would perish as a result of resource wars, starvation, and epidemics; nations would disintegrate; and the social, political, and economic order-the world as we have come to know it-would collapse, plunging the few survivors into a low-energy, hardscrabble existence. Although oil depletion would be the primary precipitant, the scope of adherents' concerns is more accurately captured by the phrase 'peak everything' (Heinberg 2007). Just as petroleum will become scarce, costly, and eventually unavailable, other natural resources will follow: freshwater (peak water); topsoil (peak dirt); overfishing (peak fish); precious metal scarcity (peak metal); peak uranium; peak natural gas, and so on. 'Peak oil' is not so much an obsession with oil but a comprehensive re-evaluation of the ecological relationship between humans and the natural resources upon which we depend.

My methodology for studying 'peakists' included interviews with peak oil leaders and rank-and-file believers, analysis of movement websites and online forums, ethnographic research conducted at peak oil conferences and intentional communities, literary analysis of peak oil novels and non-fiction works, and two online surveys conducted in 2011. Both

1. This conservative figure emerges from analysis of survey responses, web site membership, and posting patterns. See nn. 2 and 13 for more information.

(c) Equinox Publishing Ltd 2013.

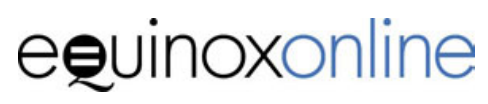


anonymous surveys used snowball sampling (or 'chain-sampling') to recruit participants, ${ }^{2}$ and specific questions ensured that respondents belonged to the target population. ${ }^{3}$ These surveys provide statistically significant support as well as a wealth of detailed responses to openended questions. As informal members of a group often ignored or caricatured by the mainstream media and marginalized by their friends, co-workers, and family, my respondents were eager to share their thoughts and experiences.

For these Americans, 'peak oil' is an ideology, an entire system of beliefs. ${ }^{4}$ It refers to a dramatic teleology in which energy scarcity leads to the collapse of the late-modern capitalist system. Believers described their awareness of peak oil in terms that are strikingly similar to a religious conversion. Many recalled the exact moment they first heard of the concept, their immediate emotional reaction, the dramatic change in their worldview, and the transformation of their personal cosmology. Many used the metaphor of wakefulness to describe this change: 'once I grasped the gravity of the situation it was like waking from a dream to find the world is not all as it seems' (McMahon 2010). For most, environmental collapse was the impetus for significant lifestyle changes. A peakist in his late thirties said, 'peak oil has changed my entire being.

2. Online surveys are especially useful for researching 'hidden' populations and populations with unpopular views (see Wright 2005). Snowball or chain sampling was chosen because it aids in recruiting hidden populations. From just two links on peak oil websites, the first survey, conducted in January 2011, received over one thousand responses in less than two weeks. I allowed any interested party to complete the surveys and asked respondents to forward the links to their 'peak oil aware' friends and acquaintances. The potential biases inherent in this methodology-such as the accuracy of self-reported information and self-selection bias-were counterbalanced by the other research methodologies. For example, the potential that the population of peakists who would answer an online survey (or even use a computer) might answer in systematically different ways from peakists who would not answer an online survey (or use a computer) was disproven by interviews with believers.

3. For example, in response to the question, 'If you had to quantify your level of certainty in the fundamental theory of peak oil-that global oil production will peak in the next decade (if it hasn't already), and that this event will have grave and potentially apocalyptic effects on the United States and around the world-on a scale of 1 to 10 , what would it be? 1 is disbelief, 10 is complete certainty', $93.8 \%$ of respondents to the first survey and $85.6 \%$ of respondents to the second answered ' 7 ' or higher.

4. I define 'ideology' as historian Eric Foner defined it, as 'the system of beliefs, values, fears, prejudices, reflexes and commitments-in sum, the social consciousness—of a social group, be it a class, a party, or a section' (1970: 4). Peakism is marked by many of the standard characteristics of recognized ideologies, including internal coherence; intellectual abstractness, specificity, and sophistication; dogmatism; and affective investment (Shils 1967).

(c) Equinox Publishing Ltd 2013.

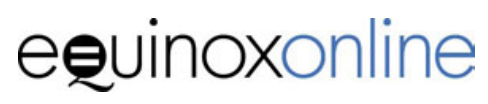


My wife and I are totally restructuring our future', while a Colorado man in his fifties reported that his new 'lifestyle is patterned after educating myself [on] how to live in a world with less oil'.$^{5}$ As a result of their 'conversion', many peakists changed occupations, purchased land, installed renewable energy sources, sold their automobiles, learned 'forgotten skills' (such as canning, farming, and sewing), and even left their partners.

As the common experience of conversion suggests, peakism bears a family resemblance to social phenomena widely acknowledged to be religious. After becoming 'peak oil aware', adherents share a belief in worldly destruction and a new conception of ethical conduct; practice rituals of prediction, prophecy, and preparation; and often seek to convert their friends and family (Taylor 2007). Survey respondents were much less likely than other Americans to believe in God and describe traditional Western religion as important to them, and some had merged their environmental and religious beliefs to create new forms of spirituality (Baker 2009). ${ }^{6}$ Indeed, believers and skeptics alike have attributed religious elements to the peak oil ideology.7

The geologic theory of 'peak oil' was first proposed by geologist M. King Hubbert in 1956. Hubbert asserted that after any given oil field or region's high point (peak) of production, when half its economically recoverable petroleum has been extracted, its productivity would inevitably decrease, and continued production would become increasingly expensive. In the 1950s, he predicted that US production would peak in the early 1970s_it occurred in 1970. The date of the technical peak of global conventional petroleum production can only be known in retrospect, since a peak is often (in graphical terms) a plateau, so we cannot be sure if we have already peaked. However, recent developments have made it clear that conventional petroleum is only part of the story. Given the expected increases in energy demand, especially from the global South, the seemingly infinite potential of unconventional sources, such as tar sands and hydrofracking, may only postpone the date of a global

5. Survey respondents are identified by their location, gender, and age. Where this data was not recorded, it is simply omitted. Male, 36-40; Colorado, male, 56-60.

6. $45 \%$ of respondents said that their religious preference was 'none', and $62 \%$ said that religion was 'not very important' to them. In a similarly worded poll of all Americans taken a year before, only $14 \%$ of Americans answered 'none', while $20 \%$ answered 'not very important', respectively (Gallup Historical Trends, online: http:// www.gallup.com/poll/1690/Religion.aspx.).

7. See, for example, the spirited debate in a thread on Peak Oil News \& Message Boards called 'Peak oil is a religion', http://peakoil.com/forums/peak-oil-is-areligion-t52427.html. 
production peak by a few decades (Brecha 2012), but the desire to find and exploit resources previously considered unreachable should not be underestimated (see Mann 2013 on the potential of methane hydrates, for example).

At the same time, the cost of energy is just as significant as its very availability, and the contemporary (Western) way of life is premised not only on an infinite supply of petroleum but on cheap oil (Black 2012). The energy returned on energy invested (EROI) of recently discovered fields as well as unconventional sources and methods is significantly lower than yesterday's petroleum. For example, the average EROI on oil extracted in the United States in the 1930s was approximately 100:1; by the 1970s, it had decreased to 30:1, and the figure was between 18:1 and 11:1 in the 2000s (Gupta and Hall 2011). EROI on Alberta's tar sands, meanwhile, has been estimated to be as low as 1.6:1 (Inman 2013). While resource depletion and diminishing EROI is certainly a major concern that should not be ignored, the precise arrival of 'peak oil' is less significant, and will have (or has not had the immediate (and obvious) apocalyptic consequences that some peak oil authors and many peakists have assumed. Of course, a distant peak would have other consequences: continuing to discover, develop, exploit, and consume hydrocarbons for decades would produce calamitous environmental effects (namely climate change) that promise unimaginable misery for future generations.

The political, social, economic, scientific, religious, and even epidemiological consequences of oil depletion have recently been the subject of scores of scholarly articles (e.g. Becken 2007; Newman 2007; Hanlon and McCartney 2008; Bardi 2009; Helm 2011), but peak oil believers have largely been overlooked by scholars because they rarely mobilized collectively or sought publicity. Instead of organizing public actions, most focus on preparing for the apocalypse. They have regularly congregated on online forums such as 'Peak Oil News \& Message Boards' and 'The Oil Drum', while constructing a rich virtual community composed of websites, blogs, Podcasts, YouTube channels, poems, cartoons, video games, and even peak oil psychotherapy. ${ }^{8}$ Attempts to create intentional communities to serve as 'lifeboats' to the 'post-carbon' world, such as the Transition Initiative (Scott-Cato and Hillier 2010; Smith 2011), have made

8. For the sake of brevity, I provide one example of each: website: The Oil Drum, http:/ /www.theoildrum.com; Blog: Clusterfuck Nation (Kunstler 2012), http:// kunstler.com/blog/; Podcast: The Survival Podcast, http:/ / www.thesurvivalpodcast. Com (2010); YouTube Channel: The Gasoline Gangsters (Jocic 2012); Poetry: The Peak Oil Poet 2012. Comic: Spoiled (Davila 2007); Online forum: Peak Oil News \& Message Boards; Peak Oil Therapy: The Feisty Life (McMahon 2011).

(c) Equinox Publishing Ltd 2013.

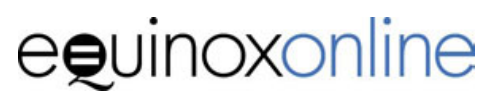


less headway in the United States than in Europe. Only one out of four respondents to my surveys had participated in such collective or political actions, and many of these attended one meeting and never returned. ${ }^{9}$ Most viewed the peak oil crisis as an imminent event that could not be averted or postponed, and endeavored to prepare themselves and their families for the inevitable.

Who are peak oil believers? Those surveyed (see notes 2 and 3) were primarily white (89-91\% of survey respondents), male (73-84\%), middleaged (average age of 47), and middle class (average yearly income between $\$ 75,000$ and 100,000$).{ }^{10}$ Although they can be found around the world - the Association for the Study of Peak Oil (ASPO) has chapters in 23 countries - the phenomenon appears to be concentrated in the United States (70-77\% of survey respondents), where believers have proven especially passionate. Within the United States respondents were concentrated in traditionally liberal states, especially in the Rocky Mountain, Pacific Northwest, and Northeast regions. ${ }^{11}$ This is to be expected given their political tendencies-56\% of American peakists described themselves as 'liberal' or 'very liberal', compared to only $20 \%$ of all Americans (Saad 2010). They were also much more highly educated than most Americans-17\% of American peakists surveyed had a $\mathrm{PhD}$ or other professional degree, $26 \%$ had earned a Master's, and $85 \%$ graduated from college, compared to 3\%, $8 \%$, and 39\%, respectively, for all Americans.

Geologists, industry insiders, and environmentalists have intermittently predicted an imminent petroleum scarcity since just after the first boom of the 1860s, but the recent peak oil movement coalesced in 2004 and reached its climax of activity and media attention in 2008. In 2003 only a handful of titles related to oil depletion were available in bookstores, by energy analysts such as Amory Lovins and 'Malthusian' environmentalists such as Paul Ehrlich (Ehrlich and Ehrlich 1974) and associated with the Club of Rome (Meadows et al. 1972; Pestel et al. 1989), but in 2004 and 2005 a slew of books on energy depletion was

9. In response to the question, 'as a result of your knowledge of peak oil, have you done any of the following', 72\% had 'prepared food or other supplies for yourself and your family', $82 \%$ had 'reduced energy usage at your current home', $24.3 \%$ had 'moved to a smaller or more energy-efficient home', and 3\% had 'moved to a Transition Town'.

10. The values here reflect the differences between the two surveys.

11. California, New York, and Washington had the highest number of total survey respondents, but the states with the highest per-capita density of peak oil believers surveyed were New Hampshire, Alaska, Colorado, Oregon, Washington, Minnesota, Wisconsin, Montana, Vermont, and Massachusetts.

(c) Equinox Publishing Ltd 2013.

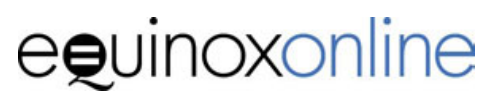


published. ${ }^{12}$ In 2004, the first of many peakist documentaries, The End of Suburbia, was released, featuring peakist authors Colin Campbell, Richard Heinberg, and James Howard Kunstler. By 2005, central movement websites (such as Peak Oil News \& Message Boards and Life After The Oil Crash) had tens of thousands of members only months after going online, and adherents were soon wearing clothing emblazoned with 'I $\bullet$ Peak Oil' and M. King Hubbert's iconic oil production bell curve.

The size of a movement with survivalist tendencies is impossible to determine definitively, since most survivalists eschew publicity, but the surprising number of peak oil believers was revealed by the number of members of and visitors to peakist websites. During September 2008 alone, for example, James Howard Kunstler's popular website, 'Clusterfuck Nation', had 190,000 unique visitors and 97,000 return visitors from the United States alone. ${ }^{13}$ By December of 2009, another site, Peak Oil News \& Message Boards, had over 19,000 active American members. Research on 'lurkers', who visit membership sites but do not join or post, shows that members sometimes comprise only ten percent of visitors (Nonnecke and Preece 2000), which suggests that almost 200,000 Americans were regularly visiting just one of many peak oil websites. The peak oil movement's web presence is impressive-by mid-2012, a Google search for 'peak oil' returned over five million web pages in English.

Three developments in the mid-2000s led to the genesis of a social movement motivated by energy concerns: the United States' invasion of Iraq in March 2003, sharp increases in the price of oil and gasoline, and growing awareness of anthropogenic climate change. Early peak oil tracts predicted that oil scarcity would lead to prolonged 'resource wars' for the remaining petroleum (Klare 2001). After the failure to uncover 'weapons of mass destruction' in Iraq, the US invasion and occupation seemed to fulfill that prophecy. Meanwhile, the average price of gasoline in the United States increased by over 300\% (from January of 2000 to July 2008), while the price of a barrel of oil increased by almost $600 \% .{ }^{14}$ The media's regular coverage of escalating gas and oil prices tethered the national mood to the price of 'black gold'. ${ }^{15}$

12. Among them: Campbell 2004; Darley 2004; Goodstein 2004; Heinberg 2004; Klare 2004; Ruppert 2004; Deffeyes 2005. Almost 70\% of respondents had never been exposed to the theory of peak oil before 2000.

13. Statistics online at http://www.StatCounter.com via link at http://www. kunstler.com.

14. The average price of gasoline rose from $\$ 1.27$ in January of 2000 to a high of $\$ 4.11$ in July 2008, while the average barrel rose from $\$ 22.68$ to a high of $\$ 133.60$.

15. For example, from December 2002 to December 2010, Time ran over one thousand stories about, related to, or at the very least mentioning oil and gas prices.

(c) Equinox Publishing Ltd 2013.

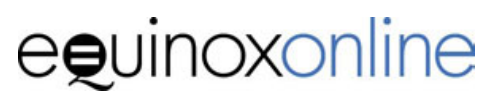


Developing awareness of anthropogenic climate change in the mid2000s also brought petroleum to the national foreground. Many peakists were led to the theory of peak oil through their research into climate change. For example, in 2009 a computer programmer from Denver said, 'I learned about peak oil in 2007 while I was studying climate change, and more and more I saw the term, started tracking it down, and got scared' (Fickas 2009). Although journalists, politicians, and pundits offered a range of explanations, peakism provided a grand narrative that offered Americans a comprehensive explanation of some of the nation's most significant events of the early to mid-2000s.

At the same time, peakism drew on strands of apocalyptic thought that have deep roots in American history.

\section{The American Apocalyptic Tradition}

Apocalypse-the 'catastrophic destruction of the world or current society, whether attributed to supernatural forces, natural forces, or human actions' (Wojcik 1999: 12) —has been an important theme throughout American history. In 2006, for example, a quarter of all Americans claimed that Jesus Christ would return to the Earth the following year (Gallup Poll 2006), while in 1999, 36 percent of Americans admitted to planning to 'stockpile food and water' in preparation for the fallout of the ' $\mathrm{Y} 2 \mathrm{~K}^{\prime}$ computer bug (Pew Research Center 2010). Connecting contemporary events to millennial prophecies is also not uncommon: in 2002, one in four Americans claimed that the Bible had predicted the September 11 attacks (Gibbs 2002). My surveys of peakists confirmed the prominence of apocalyptic belief and action in the United States: among socio-economically similar respondents from the United States and comparably industrialized nations (Canada and Western Europe), American peakists were much more likely to have stockpiled food and other supplies. ${ }^{16}$

These attitudes have a unique historical precedent in the United States. Early explorers and Puritans often cast the United States as a 'new Eden' burdened with millennial expectations, and the Shakers, Millerites, Seventh-Day Adventists, Mormons, Jehovah's Witnesses, and other groups developed apocalyptic Christian theologies (Tuveson 1968). The apocalyptic currents in American religion grew even stronger in the second half of the twentieth century, as the membership rolls of

16. $72 \%$ of American respondents had 'prepared food or other supplies for [themselves] and [their] famil[ies]' as 'a result of [their] knowledge of peak oil', compared to $60 \%$ of Canadians and Western Europeans.

(c) Equinox Publishing Ltd 2013.

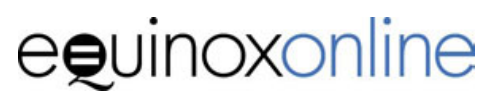


evangelical Christian denominations swelled. Premillennial dispensationalism, a theology of biblical literalism that sees the return of Christ and the millennium as imminent events, moved from the fringe of American Christianity to the mainstream (Hulsether 2007). This shift was highlighted by the popularity of premillennial evangelists and the public religiosity of Ronald Reagan and George W. Bush (Northcott 2007). Beyond Christianity, apocalypticism was a core element of scores of new religious movements that appeared in the post-WWII period, including various New Age groups. The peak oil movement has been placed in this tradition by a number of observers, described (inaccurately) as a 'liberal Left Behind' (Urstadt 2006) while derided as a 'cult' by others (e.g., Smil 2006).

Even beyond pulpits and pews, apocalypticism has maintained a consistent presence in American culture. After the end of the Cold War and the threat of nuclear annihilation, the background hum of apocalypticism in American culture assumed new forms in the 1990s. Some of this activity was due to the anticipation of the year 2000 itself, which generated countless History Channel specials on apocalyptic themes as well as anxieties such as the ' $Y 2 K^{\prime}$ ' bug (Barkun 2000). In the early 2000s, George W. Bush spoke openly about himself as a born-again evangelical, and the September 11 attacks provoked a millennial paranoia throughout the country. The British Daily Mail encapsulated this mood on September 12, 2001, when it ran the headline 'APOCALYPSE!' above an image of the World Trade Center collapsing. In the weeks after 9/11, sales of Christian prophetic literature increased by $71 \%$ (Sack 2001).

Long a staple of science fiction, post-apocalyptic visions have moved into the mainstream of American popular culture (Bendle 2005). The evangelical Left Behind series (1995-2007), which depicts a premillennial dispensational Christian eschatology, including the 'rapture' of observant Christians and the rise of the Antichrist, continued its remarkable run of popularity and was suddenly given, as Douglas Kellner noted, 'a new cultural resonance post-9/11' (2010: 123). ${ }^{17}$ Novels such as Margaret Atwood's Oryx and Crake (2003) and S.M. Stirling's Dies the Fire (2003) represented the biggest wave of apocalyptic literature since the 1960s, and the genre received a stamp of elite literary approval in 2007, when Cormac McCarthy was awarded the Pulitzer Prize for fiction for his 2006 novel The Road. TV shows such as Battlestar Galactica (2004-2009), Jericho (2006-2008), and Falling Skies (2011-2012) brought the end of the world

17. Of the 16 Left Behind novels written by Tim Lahaye and Jerry B. Jenkins, seven have reached \#1 on the New York Times, USA Today, or Publishers Weekly bestseller list, and the series has sold over 65 million books.

(c) Equinox Publishing Ltd 2013.

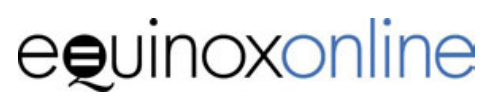


to the small screen, and teenagers and young adults immersed themselves in post-apocalyptic landscapes in video games such as Fallout (1997-2010) and the Half Life series (2001-2004). Zombie and vampire narratives, which often threatened the complete extermination of human beings, appeared in all of these formats.

Of all media platforms and genres, disaster films exerted perhaps the strongest influence on Americans and peak oil believers. The disaster genre was remarkably popular in the 1970s, with hits such as The Poseidon Adventure (1972) and The Towering Inferno (1974), but these films tended to focus on relatively small-scale crises, often isolated to a single ship, building, or airplane. When the genre returned to prominence in 1996 with Independence Day (1996), it conceived of disaster on an unprecedented scale. From 1995 to 1998, there were at least three major (high-grossing) disaster movies per year, including Independence Day (which grossed \$306 million in US theaters), Twister (\$241 million in 1996), and Deep Impact (\$140 million in 1998). ${ }^{18}$ After a brief hiatus following the September 11 attacks, the genre became even more popular. From 2004 to 2009, at least one disaster movie grossed over $\$ 150$ million in the United States each year, and in all but one year there was a second feature that took in over $\$ 80$ million. ${ }^{19}$

In the 1990s and 2000s, disaster films were increasingly related to nature and the environment. Developments in computer-generated imagery (CGI) technology, growing evidence of anthropogenic climate change, and the end of historical antagonisms led filmmakers to cast natural phenomena as their villains—as Benjamin Svetkey (1997: 3) put it, 'we have no more Russians, no more Germans, no more villains. So

18. My definition of 'disaster films' follows Nick Roddick's 1980 influential definition: they have the following characteristics: the disaster must be central to the film, as well as 'factually possible', 'largely indiscriminate', 'unexpected (though not necessarily unpredictable)' (246).

19. 2003: The Core (\$73 million); 2004: The Day After Tomorrow (\$187 million); I, Robot (\$144 million); 2005: War of the Worlds (\$234 million); 2006: World Trade Center (\$163 million); Children of Men (\$35 million); Poseidon (\$60 million); 2007: I Am Legend (\$256 million); Sunshine (\$32 million); 2008: Cloverfield (\$80 million); The Day The Earth Stood Still (\$79 million); The Happening (\$31 million); Doomsday (\$11 million); 2009: 2012 (\$166 million); Knowing (\$80 million); 2011: Battle: Los Angeles (\$212 million); Contagion (\$135 million). This list does not include Titanic (\$600 million), which has a much more limited scope than other disaster films of the late 1990s and 2000s. Zombie and vampire films and films such as The Matrix (1999) and Fight Club (1999) all contain apocalyptic themes but are generally not classified as 'disaster movies'. The genre is even more popular among made-for-TV films-from 2000 to 2011 over 50 disaster movies were released on American television networks.

(c) Equinox Publishing Ltd 2013.

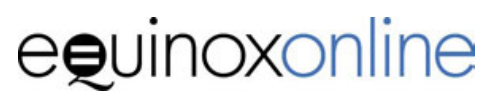


we turn to mother nature.' In Twister (1996), Volcano (1997), The Day After Tomorrow (2004), Poseidon (2006), The Core (2003), The Happening (2008), and other films, nature was portrayed as a violent, dangerous force fundamentally opposed to humankind. In The Happening (2008), the biosphere strikes back at polluting, climate-changing humans by releasing airborne neurotoxins that cause its victims immediately (and quite creatively) to commit suicide. Even when the disaster took the form of an alien invasion, many films still offered an environmental angle. In some, the aliens were seen as a part of the natural world-in War of the Worlds (2005), for example, the alien invaders literally emerge from the Earth, where they had been buried for millennia. In others, aliens were representatives of an otherwise mute nature - in the 2008 remake of The Day The Earth Stood Still, for example, Klaatu (played by Keanu Reeves) contended that 'if [humans] die, the Earth survives', and he nearly wiped out humanity in order to protect the planet. While many Americans continued to deny the existence of anthropogenic climate change, scientists' increasingly dire reports and predictions clearly converged with the eco-apocalyptic themes of these films (Gilbey 2010).

The majority of these films were summer blockbusters with large advertising campaigns that featured central events of destruction, so that even those who did not see the films got their message. Many also became staples of cable television. Although industry figures are not available, the ubiquity of disaster films on cable TV has been anecdotally noted by a number of commenters-there is even a Facebook page called 'I Always Stop If Twister or Independence Day Is On TV'. ${ }^{20}$ The number of witnesses who described the attacks of September 11 as reminiscent of a disaster movie attested to their presence in the collective imagination. Neal Gabler's 2001 editorial for the 16 September 2001 issue of the New York Times, for example, summarized the shared sense of déjà vu: 'The explosion and fireball, the crumbling buildings, the dazed and panicked victims, even the grim presidential address assuring action would be taken-all were familiar, as if they had been lifted from some Hollywood blockbuster'. Just as they permeated national consciousness, these films had an indelible influence on the eco-apocalyptic ideology of peak oil believers.

20. Online: http://www.facebook.com/pages/I-Always-Stop-if-Twister-orIndependence-Day-Is-on-Tv/113417768671144.

(c) Equinox Publishing Ltd 2013.

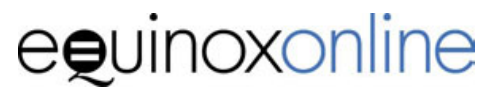




\section{Reading the Disaster Movie: Peakist Narratives and Popular Culture}

A genre as consistently popular as the disaster film succeeds because of its polyvalence. Some viewers may enjoy the use of CGI technology to create spectacular scenes, while others appreciate the unity, resolve, and heroism that most characters display in response to an imagined crisis. When scholars discuss the potential media influence of popular culture, they often portray audiences engaged in 'decoding' in a 'minority' (or 'oppositional') way that is subversive and sometimes not intended by the author, director, or artist (Hall 1973). However, an 'oppositional' reading can also represent a literal understanding of the material. While Jaws (1975) has been interpreted as a film about submarines (Willson 1977), patriarchy (Caputi 1978), and the alliance between the forces of law and order and corporatism (Jameson 1979), for the minority of viewers suffering from selachophobia, its primary lesson concerned shark attacks. Similarly, while the dominant reading of disaster films may have little to do with alien attacks or falling meteors, for viewers who were immersed in peak oil culture or deeply concerned about climate change, the influence may be quite literal. While familiar categories of identity, such as race, class, gender, religion, and politics certainly influence audience interpretations, social or psychological factorsbeliefs about sharks, for example, or the likelihood of an imminent ecological crisis—can be just as significant.

Many peakists are avid fans of apocalyptic narratives, including disaster films. Although a majority of Americans of a certain age have probably seen Independence Day, it is doubtful that nearly as many nonpeakists have watched less popular or more recent works such as The Postman (which $40 \%$ of American survey respondents had seen), Waterworld (65\%), or Children of Men (36\%) (see Fig. 1). Films of disaster and destruction became popular from 1995 to 2011 for some of the same reasons that the peak oil movement coalesced, but they also seem to have affected the way that peakists thought about themselves, their lives, and the future. Their readiness to discuss the relationship between their beliefs and these narratives presents a rare opportunity to investigate the impact of apocalyptic popular culture on real-world beliefs. ${ }^{21}$

21. A number of pop cultural texts that were also influential to peak oil believers surveyed, including the film Mad Max (1979) and apocalyptic novels like Lucifer's Hammer (Niven and Pournelle 1977), are not discussed here. Rather than explore all the pop cultural (and media) influences on peak oil believers, the scope of this essay is limited to the recent cycle of disaster films.

(c) Equinox Publishing Ltd 2013.

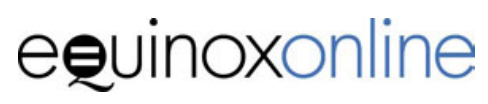




\begin{tabular}{|l|l|l|l|}
\hline Film & Year & $\begin{array}{l}\text { Box Office Gross (US } \\
\text { theaters only, in } \\
\text { millions of dollars) }\end{array}$ & $\begin{array}{l}\text { Percentage of peakists } \\
\text { who have seen the } \\
\text { film }\end{array}$ \\
\hline Independence Day & 1996 & 306.1 & 78.5 \\
\hline Mad Max & 1979 & 8.4 & 75.2 \\
\hline An Inconvenient Truth & 2006 & 24.1 & 69.8 \\
\hline Waterworld & 1995 & 88.2 & 65.2 \\
\hline The Day After Tomorrow & 2004 & 186.7 & 57.2 \\
\hline War of the Worlds & 2005 & 234.3 & 53.8 \\
\hline The Postman & 1997 & 17.6 & 38.6 \\
\hline Children of Men & 2006 & 35.6 & 36.5 \\
\hline Cloverfield & 2008 & 80.0 & 22.1 \\
\hline
\end{tabular}

When asked to comment on their interest in the disaster genre and its potential connection to their belief in an imminent real-world collapse, respondents reflected the wide range of ways that people understand their relationship to popular culture. Several granted that they enjoyed the genre but denied that it might have any impact on their beliefs: 'The serious peak oilers are serious people, not given to fantasy (as entertaining as that might be)'. ${ }^{22}$ Some confessed that they had actively resisted allowing these fictional narratives to influence their view of the future but acknowledged that they had been 'primed' to consider scenarios from disaster movies by years of exposure to these media. ${ }^{23}$ An Ohio woman said, 'I think it's hard not to be influenced by gloom and doom portrayals', and a petroleum company employee noted that 'it's difficult to avoid letting fictional portrayals influence your thinking about situations with so many variables'. A Washington man agreed that 'it's hard not to be influenced by pop culture images', but insisted that he did his best 'to research the topic and develop a rational view of what is likely to happen'. ${ }^{24}$

Most respondents admitted, however, that such attempts had probably failed because, as a science fiction fan put it, '[human beings] are sponges, and cannot help but be influenced by media to which we are exposed'. An Arizona man commented that these narratives were a 'huge influence on the "what to do about peak oil" issue', while a scientist in his fifties said he had 'read so many post-apocalyptic novels and seen even more movies that it would be difficult to deny that there

22. Connecticut, male, 51-55.

23. In the study of media effects, 'priming' is a process whereby viewers of media become more likely to think about a certain topic in a certain way due to continued exposure. See Sparks 2010: 105-106, 200-201.

24. Ohio, female, 41-45; male, 31-35; Washington, male, 41-45.

(c) Equinox Publishing Ltd 2013.

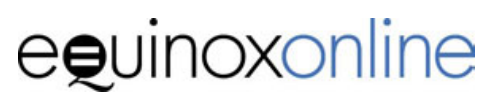


has been an influence' ${ }^{25}$ Indeed, studies of media effects regularly show that exposure to popular culture influences audiences regardless of their skepticism, media literacy, or cultural sophistication. For example, a team of British researchers found that after watching The Day After Tomorrow in 2004, audiences were 50\% more concerned about climate change than before the film (Balmford et al. 2004: 1713). ${ }^{26}$

Countless scholars have discussed or referred to the prevalence of apocalyptic narratives in contemporary American culture, but the relationship between popular culture and end-of-the-world beliefs has rarely been documented directly. My research addresses this lacuna by suggesting that cultural representations of apocalyptic themes in American popular culture-whether in film, literature, genre fiction, comic books, or video games-have and do encourage and shape some Americans' apocalyptic worldviews. In the case of the 2009 documentary Collapse, a circle of media influence was completed. Based on peakist Michael Ruppert's Crossing the Rubicon: The Decline of the American Empire at the End of the Age of Oil (2004), Collapse gave Ruppert ample screen time to explain the theory of peak oil, even as it suggested that his obsession reflects his emotional instability. For some viewers, the film introduced a new idea that proved persuasive. On the blog 'Inspired Ground', for example, one peakist chose Collapse as the film that had most influenced her life ('My Movie Influence' 2012). Another, in a review on Amazon.com, described it as 'a turning point in my life: it has changed me forever... If you read this Mike, I want to say: thank you for your legacy, for changing my life for the better and preparing our own little lifeboat for my family and I. I've been spreading your words ever since to whomever will listen' ('The movie that').

\section{The Eco-apocalyptic Influence of Disaster Films}

How did disaster films influence peak oil believers? For some, they simply dramatized and confirmed existing suspicions-as for a woman in her sixties who wrote, 'disaster movies have reaffirmed my beliefs', while a man from Oregon claimed that 'the portrayals vindicate deepseated beliefs'. A California man said that such films 'are all related to a common idea of what it would be like in our imaginations', so that 'art is

25. Male, 46-50; Arizona, male, 31-35; male, 41-45.

26. In this study, 'concern' was measured by the audience's allocation of hypothetical money to climate change mitigation (as opposed to four other worthy causes) and the emissions-reducing actions that respondents said they planned to take before and after seeing the film.

(c) Equinox Publishing Ltd 2013.

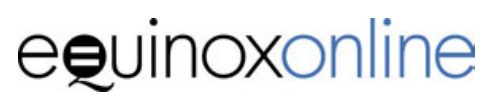


imitating life'. Other respondents held that disaster narratives had opened their minds to potential futures which might just come to passa Colorado man noted that 'fiction can be a cathartic way to release emotion and fear around outcomes', but 'fiction can also be prophetic'. A 'prepper' from California noted that the quantity of disaster films had influenced the way he conceives of the future: 'I haven't been convinced of [sic] one in particular, but they do expand the realm of possibilities', and an Oklahoma woman in her forties said that in some ways they have raised fears that might not have been there'. ${ }^{27} \mathrm{~A}$ Minnesota woman in her early thirties summed up the general influence of apocalyptic popular culture: 'I think fiction has made me more of a doomer'. ${ }^{28}$

From survey responses and analysis of the aforementioned disaster films and the peak oil ideology, four areas of influence emerged. The first is the portrayal of nature as a partial agent of social change. In most disaster films, nature is not the background against which human drama develops but an active agent of change. A tornado, tidal wave, or alien attack is the narrative's prime mover, compelling humans to unite across political, racial, and socio-economic boundaries. Similarly, for some peakists, oil depletion as a natural 'limit' is itself a change agent. Many peakists speak of the peaking of global petroleum production as an event with destructive capabilities, akin to a meteor or earthquake. One survey respondent wrote that 'peak oil will have a permanent and measurable effect on my day-to-day living', and another claimed that 'peak oil will drag down any economic systems that remain dependent on fossil fuels' ${ }^{29}$ In its symbolic ascription of agency and power (and the potential for revenge) to the natural environment, peakism resembles both nature religions and deep ecology.

In both disaster film and peak oil narratives, hope is to be found in disaster's wake, since cataclysmic events provide a means of regeneration through crisis. In disaster films, tectonic plates, volcanoes, and even flora are potential villains - primal powers that threaten to destroy lives and nations alike. In response, humans are forced to pull together across

27. A 'prepper' is an individual who is actively preparing for an impending crisis or collapse, usually by stockpiling food and other supplies and learning 'forgotten' skills such as canning, sewing, farming, and building with natural materials. For most American survivalists, 'prepping' also involves purchasing firearms but this seems to be less widespread among peakists, reflecting either a liberal and leftist commitment to non-violence or a lack of familiarity with guns, if not both.

28. Female, 61-65; Oregon, male, 51-55; California, male, 36-40; Massachusetts, male, 46-50; Minnesota, male, 31-35; Colorado, male, 36-40; California, male, 71-75; Oklahoma, female, 46-50; and Minnesota, female, 31-35.

29. United States, male, 31-35; and Maryland, male, 41-45.

(c) Equinox Publishing Ltd 2013.

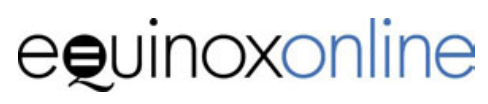


divisions of race, gender, class, religion, politics, and nationality. Ultimately, this unification is more consequential than the material damage and lives lost. In 1997's Volcano, for example, black and white Angelenos unite to contain the flow of lava that threatens their city. As volcanic ash rains on the denizens of Los Angeles-a city whose racial violence had recently been the subject of a national spotlight in the wake of the Rodney King verdict-a boy remarks that 'everybody looks exactly the same'. Even in darker films, such as The Core (2003) and The Knowing (2009), the conclusions rarely focus on death and destruction, but move on to highlight the lessons learned and the strength of the survivors, as the music swells. Under attack from nature, survivors recognize their true priorities: old friends become lovers, uninterested or workaholic fathers become dedicated parents, and families pull together.

Similarly, naturally occurring scarcity plays a crucial role in the kind of positive transformation evident in many peakist narratives. Most of my respondents were extremely pessimistic about the potential of political action and existing institutions to address major challenges such as resource depletion and climate change, due in part to their rare (and quite accurate) awareness of the scale and gravity of these issues. Like other politically alienated people, many peakists seemed to imagine the unlikelihood of change, as Nikolas Kompridis put it, to be 'a symptom of [their] powerlessness rather than as the product of [their] agency' (2006: 247). Many respondents (sometimes secretly) looked forward to the peak oil crisis-in my surveys, one out of three peakists admitted to feeling 'excitement' about the post-apocalyptic world. An independent survey found that $37 \%$ of peakists were more 'excited' than 'worried' about the 'post-peak years', and 50\% saw peak oil as an 'opportunity', not a 'problem' (Howard 2009). Examining James Howard Kunstler's prophetic novel, World Made By Hand (2008), which 78\% of respondents had read and many described as highly realistic, shows that some believers consider the peak oil crisis (or its aftermath) as redemptive.

Set in the 2020s two decades after the onset of peak oil in a small town in upstate New York, World Made By Hand is presented as a dystopia, but its post-apocalyptic world is actually superior to the present in many ways. Union Grove is a real community founded on mutual aid (Kropotkin 1902). The crash of the oil economy has finally caused the fall of capitalism itself, and residents employ a pre-capitalist credit economy, simple but fair. The survivors, as one character puts it, 'eat real food instead of processed crap full of chemicals. We're not jacked up on coffee and television and sexy advertising all the time. No more anxiety about credit card bills' (Kunstler 2008: 38). The government's absence has forced survivors to embrace a kind of Emersonian self-reliance, and they

(c) Equinox Publishing Ltd 2013.

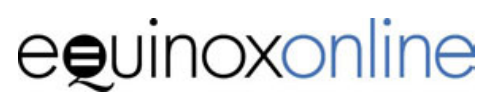


have gained the dignity of working freely for themselves (Emerson 1841). They produce not only their own food and housing but their own entertainment, medicine, alcohol, and recreational drugs. To emphasize that post-apocalyptic cuisine is actually superior to that common in fossil-fueled industrial civilization, in this future there are no chemicals or trans fats, and the place is a locavore's dream, made clear as the narrator lingers over every culinary description. Industry and pollution have come to a halt, and survivors enjoy a renewed sensitivity to and connection with the natural world. For a group that is largely white, male, and educated, it is also noteworthy that the white, male, former white-collar narrator finds in his post-peak life a renaissance masculinity, as a carpenter, a sheriff, a firefighter, and a musician, who also enjoys a great deal of sexual freedom. ${ }^{30}$ In the peakist vision of the future, then, collapse provides a means of social and environmental regeneration. ${ }^{31}$

Fatalism provides a second connection between disaster films and peakism. In both, collective or political efforts fail to prevent an apocalyptic event or even guarantee survival. In disaster movies such as The Day After Tomorrow (2004), political action is portrayed as futile-the powers that be are too entrenched, the government unwilling to listen until it is too late. Survival is only to be found in small groups, primarily the family. Although many peakists acknowledge that only collective preparations for peak oil and climate change will be successful, most responses were restricted to the private sphere. The 'Transition Town' initiative, a collective movement of urban transformation and intentional communities, has received a good deal of attention in the media (e.g. Lawrence 2007; Mooallem 2009) and in academic journals (e.g., North 2010; Smith 2011), but few respondents were active in such collective or political endeavors. Most said that their chief priority was 'protecting themselves and their family from the immediate consequences of peak oil' instead of 'educating others' or 'working with others to try to avert the worst consequences'. Peak oil and other environmental issues were not seen as problems that required political solutions, but raised the kinds of profound questions often reserved for religious phenomena. Instead of engaging in political action, most peakists prepared for an inevitable collapse. After becoming 'peak oil aware', almost three out of

30. On the question of gender in the peak oil movement and World Made By Hand, see Astyk 2005, 2008.

31. As Robin Globus and Bron Taylor have argued, such narratives of 'postapocalyptic "redemption" in the form of revitalized, Earth-friendly human societies and restored ecological health' are typical of the strain of environmental apocalypticism typically found among 'radical environmentalists, Pagans, and New Agers' (2011: 637-38).

(c) Equinox Publishing Ltd 2013.

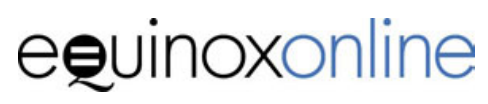


four respondents began stockpiling food, over a third purchased a more energy-efficient car, one out of four moved to a smaller or more energyefficient home, and one out of five changed their occupation. There are many potential explanations for a fatalistic attitude toward political solutions, but the influence of models of action in popular culture should not be discounted. As a Canadian peakist in her late thirties put it, 'the prevalence of survivalist films make[s] people think like survivalists'. ${ }^{32}$

Third, apocalyptic pop culture regularly offers a character on whom peakists may (unconsciously) model themselves. Almost every recent disaster film contains a Cassandra whose warnings go unheeded; typically a white male (like most peakists), he is better prepared than others when disaster strikes and thereby survives along with his family. The prophet serves as a model for the viewer or reader, who can now imagine himself as more prepared for the crisis after witnessing the narrative. As George Slusser (2000: 120) noted, this is a key (and rarely appreciated) aspect of many apocalyptic texts: the novel or film as a survival guide, 'an "experiment" in survivalism....an intellectually contrived situation, voluntarily begun and ended, a training exercise in Armageddon'. Or, as one peakist put it, 'people love a good disaster movie/book' because they can believe 'that they' $\mathrm{d}$ be one of the smart ones that survive' ${ }^{33}$

In The Day After Tomorrow (2004), for example, the prophet is Jack Hall (Dennis Quaid), a paleoclimatologist whose warnings of abrupt climate change fall on deaf ears. In the blockbuster 2012 (2009), the prophet is Jackson Curtis (John Cusack), a science fiction author whose familiarity with 2012 conspiracy theories enables him to save himself and his family from earthquakes and a global flood. Similarly, the protagonist of World Made By Hand is a former peak oil prophet. A peakist from Kansas pointed to this link between fiction and psychological disaster preparation when he wrote that 'some of these portrayals' in apocalyptic popular culture 'can appear to be almost heroic in nature. It would seem some [peakists] think they could be the "last one standing" because of their prep[aration]s, but I think that is natural at some level.' Another adherent, in his early fifties, acknowledged that he found apocalyptic films to be useful because they 'let me play out scenarios in my head so that if/when confronted with similar situations, I can resist a mindless fight/ flight/freeze condition'. ${ }^{34}$

32. Washington, female, 36-40. On the causes of peakist fatalism, see SchneiderMayerson 2013.

33. Canada, male, 41-45.

34. California, male, 41-45; Kansas, male, 36-40; and Texas, male, 51-55.

(c) Equinox Publishing Ltd 2013.

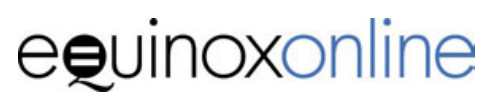


Film critic David Denby wrote of disaster films that the audience is 'put in the position of wanting to see the people melt (otherwise there's no movie); we root for the disaster' (1997: 58). In a similar way, some peak oil believers come to 'root for' the peak oil crisis. If it occurs, they are prophets and potential saviors. If it does not, they are (to use their own words) just 'kooks', 'crackpots', and 'survival nuts' who fell for a 'fringe internet-based theory'.$^{35} \mathrm{~A}$ former peakist described the dynamic between prophecy and fulfillment more cynically: 'some people like to feel they are significant players in pivotal times, so they make this crap up ${ }^{\prime}{ }^{36}$ For many peakists, as in disaster films, the prophet can do little except prepare himself and his family-and perhaps even hope for the worst.

\section{The Broader Eco-apocalyptic Influence of Disaster Films}

Whether or not the peak oil prediction of apocalyptic social collapse is 'made up', the statements of peak oil believers and the close resemblance between their ideology and the plots of popular disaster films suggests that, at the very least, the way in which they have manifested their concerns has been heavily influenced by popular culture. ${ }^{37}$ Although peakists' level of anxiety over an imminent peak oil crisis may turn out to be misguided, the influence of eco-apocalyptic narratives on conceptions of environmental change should give us pause. If, as I have suggested, apocalyptic narratives provide a template by which we understand environmental change, it is also likely that the aforementioned films—as well as similar narratives in literature, television, and video games, and dramatic pronouncements from scientists and journalists about 'tipping points' and 'last chances' - affect how all Americans conceive of other environmental threats, such as anthropogenic climate change.

The final connection between eco-apocalyptic popular culture and peakism is the most important. Hollywood disaster films epitomize the

35. Nebraska, male, 41-45; New York, male, 36-40; California, male, 36-40; and male, 46-50.

36. Male, 56-60.

37. Due to the recent boom in extraction by unconventional methods (such as hydofracking) and of unconventional sources (such as tar sands and oil shale), predictions of a sudden peak in global oil production have died down. However, some peakists note that climate change and peak oil are two sides of a coin-if the 'age of oil' ends soon, as peakists believe, it would indeed constitute a calamitous event; should we continue burning fossil fuels at the present rate for decades, the consequences of climate change will be that much worse than current estimates predict. 
American cultural tendency to emphasize the spectacular, the explosive, and the immediate over the mundane, gradual transformations that are far more common in both social and environmental change. A number of survey respondents argued that the lack of non-apocalyptic depictions of environmental change almost guaranteed that disaster films would influence the way they thought about such issues. Noting the connection between fictional and political narratives, a peakist from Washington, DC argued that

Because our leaders and our society have refused to conduct an open, honest, thorough discussion about this issue, we are left to our own wild imaginations and the imaginations of Hollywood marketers to develop images of likely futures. ${ }^{38}$

Similarly, a Californian bemoaned the lack of competing mass-culture predictions, contending that 'we need artists to describe for us a positive vision of the future'..$^{39} \mathrm{By}$ 'positive vision', he was not referring to utopian dreams of technological salvation, but to narratives of a nation or planet dealing with urgent environmental problems in a serious, thoughtful, and concerted way-which may sound as unlikely to some readers as the plots of Armageddon (1998) and The Core (2003).

Although some peakists viewed the consequences of resource depletion as a slow, 'long emergency' (Kunstler 2005), many adherents reverted to the more familiar apocalyptic mode. The difference between narratives of sudden and gradual change has implications far beyond this subculture. In recent work, Rob Nixon has emphasized the imperative to recognize and represent environmental 'slow violence', which is 'violence that occurs gradually and out of sight, a violence of delayed destruction that is dispersed across time and space', as opposed to 'an event or action that is immediate in time, explosive and spectacular in space, and [that erupts] into sensational visibility' (Nixon 2011: 2). Several survey respondents agreed. A man from North Carolina said that 'it would be great to see a fictional powerdown scenario to give people another scenario to contemplate', using Richard Heinberg's phrase for a 'species-wide effort toward self-limitation' (2004: 88) to transition away from our oil economy and avoid a violent global collapse. ${ }^{40}$ As scholars such as Mike Hulme (2010) have noted, the prevalence of the apocalyptic mode in popular culture, as well as communications from scientists and environmentalists, has contributed to Americans' lack of a model of action in the face of an ecological

38. District of Columbia, male, 36-40.

39. Male, 51-55.

40. North Carolina, male, 51-55.

(c) Equinox Publishing Ltd 2013.

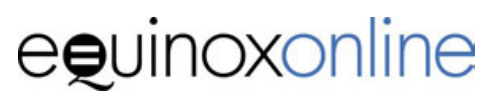


situation that is similarly catastrophic but slower and more complicated than that which Jake Gyllenhaal and Dennis Quaid faced in The Day After Tomorrow (2004). This is, to borrow Kunstler's term, a 'long emergency' with no end in sight, characterized by a rising concentration of carbon dioxide, rampant deforestation, topsoil erosion, biodiversity loss, environmental toxification, and gradual resource depletion.

Due to their quasi-religious commitment to peakism, peak oil believers may be more drawn to and thus more easily influenced by apocalyptic popular culture than most Americans. Still, we should recall just how popular the disaster/apocalypse trope has been in twenty-first-century American culture, how historically persistent it has proven in the United States, and how few 'likely' alternative narratives for environmental issues (corporate greenwashing campaigns not included) are presented in popular culture. As Nixon notes, 'a major challenge' for environmentalists 'is representational: how to devise arresting stories, images, and symbols adequate to the pervasive but elusive violence of delayed effects'. That films and visual media have almost exclusively portrayed a 'sudden catastrophe' instead of a more realistic 'slow crisis' (Buell 2004: 186) has left Americans all the more unequipped to comprehend and confront contemporary environmental problems. As our responses (or lack thereof) become even more critical in the coming years, will Hollywood and other cultural tastemakers present a new narrative? What would it look like? Given the deep roots of American apocalypticism and the influence of fictional narratives on real-world beliefs, these questions should be of concern not only to scholars of resource depletion and climate change, but to anyone interested in our transition to a more sustainable world.

\section{Appendix: Media}

2012. 2009. Directed by Roland Emmerich.

Armageddon. 1998. Directed by Michael Bay.

Battle: Los Angeles. 2011. Directed by Jonathan Liebesman.

Battlestar Galactica. 2004-2009. Created by Glen A. Larson.

Children of Men. 2006. Directed by Alfonso Cuarón.

Cloverfield. 2008. Directed by Matt Reeves.

Collapse. 2009. Directed by Chris Smith.

Contagion. 2011. Directed by Stephen Soderbergh.

Core, The. 2003. Directed by Jon Amiel.

Day After Tomorrow, The. 2004. Directed by Roland Emmerich.

Day The Earth Stood Still, The. 2008. Directed by Scott Derrickson.

Deep Impact. 1998. Directed by Mimi Leder.

Doomsday. 2008. Directed by Neil Marshall.

End of Suburbia, The. 2004. Directed by Gregory Greene.

(c) Equinox Publishing Ltd 2013.

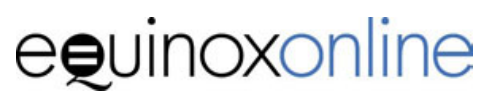


Falling Skies. 2011-2012. Produced by John Ryan.

Fallout. 1997-2011. Developed by Interplay Entertainment.

Half Life. 1998-2001. Developed by Valve Corporation and Gearbox Software.

Happening, The. 2008. Directed by M. Night Shyamalan.

I, Robot. 2004. Directed by Alex Proyas.

I Am Legend. 2007. Directed by Francis Lawrence.

Independence Day. 1996. Directed by Roland Emmerich.

Jaws. 1975. Directed by Steven Spielberg.

Jericho. 2006-2008. Produced by John Turteltaub.

Knowing. 2009. Directed by Alex Proyas.

Poseidon. 2006. Directed by Wolfgang Petersen.

Poseidon Adventure, The. 1974. Directed by John Guillermin.

Sunshine. 2007. Directed by Danny Boyle.

Towering Inferno, The. 1972. Directed by Ronald Neame.

Twister. 1996. Directed by Jan de Bont.

War of the Worlds. 2005. Directed by Stephen Spielberg.

Waterworld. 1995. Directed by Kevin Reynolds.

World Trade Center. 2006. Directed by Oliver Stone.

\section{References}

Astyk, Sharon. 2005. 'Peak Oil Is Still a Women's Issue and Other Reflections on Sex, Gender and the Long Emergency'. Online: http://scienceblogs.com/ casaubonsbook/2010/01/31/peak-oil-is-still-a-womens-iss/.

- 2008. 'Why Are the Mean Girls Picking on World Made by Hand?'. Online: http://www2.energybulletin.net/node/43766.

Atwood, Margaret. 2003. Oryx and Crake (Toronto: McClelland \& Stewart).

Baker, Carolyn. 2009. Sacred Demise: Walking the Spiritual Path of Industrial Civilization's Collapse (iUniverse).

Balmford, Andrew et al. 2004. 'Hollywood, Climate Change, and the Public', Science 305.5691: 1713.

Bardi, Ugo. 2009. 'Peak Oil: The Four Stages of a New Idea', Energy 34: 323-26. Doi: 10.1016/j.energy.2008.08.015.

Barkun, Michael. 2000. 'Millennium Culture: The Year 2000 as a Religious Event', in Martha F. Lee (ed.), Millennial Visions: Essays on Twentieth-century Millenarianism (Westport, CT: Praeger): 41-54.

Becken, Susanne. 2007. 'Developing Indicators for Managing Tourism in the Face of Peak Oil', Tourism Management 29.4: 695-705. Doi: 10.1016/j.tourman.2007.07.012.

Bendle, Mervyn F. 2005. 'The Apocalyptic Imagination and Popular Culture', Journal of Religion and Popular Culture 11: n.p.

Black, Brian C. 2012. 'Oil for Living: Petroleum and American Conspicuous Consumption', Journal of American History 99.1: 40-50. Doi: 10.1093/jahist/jas022.

Brecha, Robert J. 2012. 'Logistic Curves, Extraction Costs, and Effective Peak Oil', Energy Policy 51: 586-97. Doi: 10.1016/j.enpol.2012.09.016.

Buell, Frederick. 2004. From Apocalypse to Way of Life: Environmental Crisis in the American Century (New York: Routledge).

Campbell, Colin. 2004. The Coming Oil Crisis (London: Multi-Science Publishing).

\section{eevinoxonline}


Caputi, Jane. 1978. 'Jaws as Patriarchal Myth', Journal of Popular Film 6.4: 305-26. Doi: 10.1080/00472719.1978.9943447.

Darley, Julian. 2004. High Noon for Natural Gas: The New Energy Crisis (White River Junction, VT: Chelsea Green Publishing).

Davila, Claudia. 2007. Spoiled. Online: http:/ / girloftheknowing.blogspot.com.

Deffeyes, Kenneth S. 2005. Beyond Oil: The View from Hubbert's Peak (New York: Hill \& Wang).

Denby, David. 1997. ‘Lava Story', New York, 12 May 1997.

Ehrlich, Paul R., and Anne H. Ehrlich. 1974. The End of Affluence: A Blueprint for Your Future (New York: Ballantine Books).

Emerson, Ralph Waldo. 1841. 'Self-Reliance', in Essays (Boston: J. Munroe \& Co.).

Fickas, Bill. 2009. Personal interview. 12 November.

Foner, Eric. 1970. Free Soil, Free Labor, Free Men: The Ideology of the Republican Party Before the Civil War (New York: Oxford University Press).

Gabler, Neal. 2001. 'This Time, the Scene Was Real', New York Times, 16 September 2001, Section 4:2.

Gallup Poll. 2006. 'Y2K Millennium Bug-Wave 3'. Online : http://brain.gallup. com/documents/questionnaire.aspx?STUDY=P9908039.

Gibbs, Nancy. 2002. 'Apocalypse Now', Time 160.1: 38-46.

Gilbey, Ryan. 2010. 'Climate Change Is Inspiring the Ultimate Scary Movies', The Guardian, 1 January: 28.

Globus, Robin, and Bron Taylor. 2011. 'Environmental Millennialism', in Catherine Wessinger (ed.), Oxford Handbook of Millennialism (Oxford: Oxford University Press): 628-46. Doi: 10.1093/oxfordhb/9780195301052.003.0032.

Goodstein, David. 2004. Out of Gas: The End of the Age of Oil (New York: Norton).

Gupta, Ajay K., and Charles A.S. Hall. 2011. 'A Review of the Past and Current State of EROI Data', Sustainability 3.10: 1796-809. Doi: 10.3390/su3101796.

Hall, Stuart. 1973. 'Encoding and Decoding in the Television Discourse', paper for the Council of Europe Colloquy, University of Leicester.

Hanlon, Phil, and George McCartney. 2008. 'Peak Oil: Will It Be Public Health's Greatest Challenge?', Public Health 122.7: 647-52. Doi: 10.1016/j.puhe. 2008.03.020.

Heinberg, Richard. 2004. Powerdown: Options and Actions for a Post-Carbon World (Gabriola Island, BC: New Society Publishers).

- 2007. Peak Everything: Waking Up to a Century of Decline (Gabriola Island, BC: New Society Publishers).

Helm, Dieter. 2011. 'Peak Oil and Energy Policy: A Critique', Oxford Review of Economic Policy 27.1: 68-91. Doi: 10.1093/oxrep/grr003.

Howard, James L. 2009. 'Global Peak Oil Survey 2009'. Online: http://www. powerswitch.org.uk/portal/index.php?option=com_content\&task=view\&id= 2971\&Itemid=77.

Hulme, Mike. 2010. 'Four Meanings of Climate Change', in Stefan Skrimshite (ed.), Future Ethics: Climate Change and Apocalyptic Imagination (London: Continuum): 27-58.

Hulsether, Mark. 2007. Religion, Culture and Politics in the Twentieth-Century United States (New York: Columbia Press).

Inman, Mason. 2013. 'The True Cost of Fossil Fuels', Scientific American 308: 58-61. Doi: 10.1038/scientificamerican0413-58.

\section{eevinoxonline}


Jameson, Frederic. 1979. 'Reification and Utopia in Mass Culture', Social Text 1: 130-48.

Doi: $10.2307 / 466409$.

Jocic, Dusko. 2012. 'The Gasoline Gangsters'. Online: http:/ / www. gasolinegangsters. com.

Keane, Stephen. 2001. Disaster Movies: The Cinema of Catastrophe (London: Wallflower).

Kellner, Douglas. 2010. Cinema Wars: Hollywood Film and Politics in the Bush-Cheney Era (Oxford: Wiley-Blackwell).

Klare, Michael T. 2001. Resource Wars: The New Landscape of Global Conflict (New York: Metropolitan Books).

- 2004. Blood and Oil: The Dangers and Consequences of America's Growing Oil Conspiracy (New York: Metropolitan Books).

Kompridis, Nikolas. 2006. Critique and Disclosure: Critical Theory between Past and Future (Cambridge, MA: Massachusetts Institute of Technology Press).

Kropotkin, Peter. 1902. Mutual Aid: A Factor of Evolution (London: W. Heinemann).

Kunstler, James H. 2005. The Long Emergency: Surviving the Converging Catastrophes of the Twenty-First Century (New York: Grove/Atlantic Monthly Press).

- 2008. World Made By Hand (New York: Atlantic).

—. 2012. 'Clusterfuck Nation'. Online: http:/ / kunstler.com/blog.

Lawrence, Felicity. 2007. 'Pioneering Welsh Town Begins the Transition to a Life without Oil', The Guardian, 7 April.

'Life After the Oil Crash', 2009. Online: http:/ / www.lifeaftertheoilcrash.net/.

Mann, Charles C. 2013. 'What If We Never Run Out of Oil?', Atlantic, 24 April. Online: http:/ / www.theatlantic.com/magazine/archive/2013/05/what-if-we-neverrun-out-of-oil/309294/.

McCarthy, Cormac. 2006. The Road (New York: Alfred A. Knopf).

McMahon, Kathy. 2010. 'Stages of Peak Oil Awareness'. Online: http://www. peakoilblues.org/blog/?p=2381.

. 2011. 'The Feisty Life'. Online: http:/ / www.feistylife.com/.

Meadows, Donella H., and Club of Rome. 1972. The Limits to Growth: A Report for the Club of Rome's Project on the Predicament of Mankind (New York: Universe Books).

Mooallem, Jon. 2009. 'The End Is Near! (Yay!)', New York Times Magazine, 19 April: MM28.

'My Movie Influence'. 2012. Online: http:/ / www.inspired-ground.com/my-movieinfluence-collapse-2009/.

Newman, Peter. 2007. 'Beyond Peak Oil: Will Our Cities Collapse?', Journal of Urban Technology 14.2: 15-30. Doi: 10.1080/10630730701531666.

Niven, Larry, and Jerry Pournelle. 1977. Lucifer's Hammer (Chicago: Playboy Press).

Nixon, Rob. 2011. Slow Violence and the Environmentalism of the Poor (Cambridge, MA: Harvard University Press). Doi: 10.4159/harvard.9780674061194.

Nonnecke, Blair, and Jenny Preece. 2000. 'Lurker Demographics: Counting the Silent', Conference on Human Factors in Computing Systems, The Hague, Netherlands.

North, Peter. 2010. 'Eco-localisation as a Progressive Response to Peak Oil and Climate Change: A Sympathetic Critique', Geoforum 41.4: 585-94. Doi: 10.1016/i.geoforum.2009.04.013.

Northcott, Michael S. 2007. An Angel Directs the Storm: Apocalyptic Religion and American Empire (London: SCM Press).

'Peak Oil Is a Religion'. 2012. Online: http://peakoil.com/forums/peak-oil-is-areligion-t52427-30.html.

\section{eevinoxonline}


'Peak Oil News \& Message Boards'. 2012. Online: http:/ / peakoil.com.

Peak Oil Poet. 2012. Online: http://www.oilcrash.com/articles/poems.htm.

Pestel, Eduard, and Club of Rome. 1989. Beyond the Limits to Growth: A Report to the Club of Rome (New York: Universe Books).

Pew Research Center. 2010. 'Public Sees a Future Full of Promise and Peril'. Online: http:/ / www.people-press.org/2010/06/22/public-sees-a-future-full-ofpromise-and-peril.

Roddick, Nick. 1980. 'Only the Stars Survive: Disaster Movies in the Seventies', in David Bradby, Louis James, and Bernard Sharratt (eds.), Performance and Politics in Popular Drama: Aspects of Popular Entertainment in Theatre, Film and Television 1800-1976 (Cambridge: Cambridge University Press): 243-70. Doi: $10.1017 /$ CBO9780511659423.018.

Ruppert, Michael. 2004. Crossing the Rubicon: The Decline of the American Empire at the End of the Age of Oil (Gabriola Island, BC: New Society Publishers).

Saad, Lydia. 2010. 'Conservatives Remain the Largest Ideological Group in U.S.', Gallup, 12 January 2012.

Sack, Kevin. 2001. 'Apocalyptic Theology Revived by Attacks', New York Times, 23 November: A17.

Schneider-Mayerson, Matthew. 2013. 'From Politics to Prophecy: Environmental Quiescence and the "Peak Oil" Movement', Environmental Politics 22.5: 866-82. Doi: $10.1080 / 09644016.2013 .818303$.

Scott-Cato, Molly, and Jean Hillier. 2010. 'How Could We Study Climate-related Social Innovation? Applying Deleuzean Philosophy to Transition Towns', Environmental Politics 19.6: 869-87. Doi:10.1080/09644016.2010.518677.

Shils, Edward. 1967. 'Ideology: The Concept and Function of Ideology', in Paul Edwards (ed.), Encyclopedia of Philosophy, vol. 4 (New York: MacMillan): 975-78.

Slusser, George. 2000. 'Pocket Apocalypse: American Survivalist Fictions from Walden to The Incredible Shrinking Man', in David Seed (ed.), Imagining Apocalypse: Studies in Cultural Crisis (New York: St Martin's Press): 118-35.

Smil, Vaclav. 2006. 'Peak Oil: A Catastrophic Cult and Complex Realities', World Watch Magazine 19.1: 22-24.

Smith, Amanda. 2011. 'The Transition Town Network: A Review of Current Evolutions and Renaissance', Social Movement Studies 10.1: 99-105. Doi: 10.1080/14742837.2011.545229.

Sparks, Glenn G. 2010. Media Effects Research (Boston: Wadsworth).

Stirling, S.M. 2003. Dies the Fire (New York: Roc Books).

Survival Podcast. 2010. Online: http:/ / www.thesurvivalpodcast.com/episode-516-anew-look-at-peak-oil.

Svetkey, Benjamin. 1997. Entertainment Weekly: 3-4.

Taylor, Bron. 2007. 'Exploring Religion, Nature and Culture-Introducing the Journal for the Study of Religion, Nature and Culture', JSRNC 1: 5-24. Doi: 10.1558/jsrnc.v1i1.5.

'The Movie that Changed my Life'. 2010. Amazon.com. Online: http:/ / www.amazon. com/Collapse-Michael-Ruppert/productreviews/B003CJXJ8Q?pageNumber=7.

Tuveson, Ernest L. 1968. Redeemer Nation: The Idea of America's Millennial Role (Chicago: University of Chicago Press).

\section{eevinoxonline}


Urstadt, Brian. 2006. 'Imagine There's No Oil: Scenes from a Liberal Apocalypse', Harper's Magazine, August: 31-40.

Willson, Robert. 1977. 'Jaws as Submarine Movie', Jump Cut: A Review of Contemporary Media 15: 32-33.

Wojcik, Daniel N. 1999. The End of the World as We Know It: Faith, Fatalism and Apocalypse in America (New York: New York University Press).

Wright, Kevin B. 2005. 'Researching Internet-Based Populations: Advantages and Disadvantages of Online Survey Research, Online Questionnaire Authoring Software Packages, and Web Survey Services', Journal of Computer-Mediated Communication 10.3: 11. 